\title{
Professional Development in Greek Military Services. Searching a Dominant Leadership
} Style

\section{Elissavet Karageorgou}

MSc, MEd, PhD Cand. Harokopio University, Athens, Greece,

Georgios Deligeorgiou

MSc, PhD Cand. Harokopio University, Athens, Greece

Lazaros Rizopoulos

BA, MSc, PhD Cand. Peloponnese University, Tripoli, Greece

Theodoros Stefou

MSc, PhD Cand. Harokopio University, Athens, Greece

\begin{abstract}
Leadership is a focal concept to the functioning of all modern organizations. The leader of an organization is the architect required to create vision and strategy. Management and leadership, the third ranking of administration, is a motivating and guiding Human Resource (HR) in order to contribute effectively to achieving the objectives of an organization. A military service is a complex living mixture of body collections, roles, rules and culture. In terms of numbers, the Greek Army has hundreds of hierarchical structures and about 70,000 active personnel. There is a clear gradation of hierarchy and a code of ethics. At the same time, there is individual leadership, where a military leader commands his/her unit with a distinct and personal style. This research aims at seeking a leadership style based on a personal level to be exercised within the framework of strict structures of HR, that, when effectively exercised, helps younger military leaders improve themselves and also to be used as a proper model in a common basis for thinking and learning about leadership. Fifty officers provided relevant information by filling-in a corresponding number of Multifactor Leadership Questionnaires (MLQ) with fourty five close-ended questions, which count the extent of leadership styles as Full Range Leadership: Transformational, Transactional and Avoidant. The MLQ also examines Leadership Outcomes: Extra Effort, Effectiveness and Satisfaction. Data elaboration and statistical analysis were performed. The dominant leadership style and potential vision resulting from this style are indentified.
\end{abstract}

Keywords: Leadership, Greek Military Force

\section{Introduction}

Leadership is known to be a set of procedures needed by organisations not only for their existanse but also for improving their ability of adapting to conditions when they are changed. Leadership determines the future of the organisation orients personnel according to the operational vision and inspires them to accomplish goals, despite any obstacles that should arise.

The concept of leadership is examined not only as the administrative post of the superior, but also as the style he uses as he manages. In a rapidly changing world, where constant growth of agencies and organizations is a prerequisite, maintaining competitiveness and comparative advantage on offering their services, in order to fulfill their function, depends primarily on the Management - Leadership style running through them. 


\section{Literature Review}

Trying to find the interpretation of the term Management in literature, it can be defined as the process of efficient use of organizational resources to pursue the primary objectives of the organization. Resources are existing factors that are owned or controlled by the organization and they are distinguished as human (management, skills, knowledge), as organizational (planning and organizing systems, coordination and control methods) and as physical (technology, equipment, hardware, software). The ability of a resource to become a source of a sustainable competitive advantage depends on four (4) basic characteristics (Niveroglou, 2008):

(1) To be usable in the sense of the possibility of exploitation of environmental opportunities.

(2) To be rare among existing and potential competitors.

(3) To be difficult to a complete replication.

(4) There are no substitutes that could be used by competitors.

From the term Management derives the term Manager, indicating the person who performs work by using people and other material resources. The exact meaning of the term Manager is limited to that person who exercises its managerial functions to achieve results through other people. This means that a Manager is responsible for other people's results and at the same time he has the right to exercise power over them. In Greek, the concept of manager is best expressed in the concept of Head - Director regardless of hierarchical level he is.

According to the Hellenic Armed Forces (AF), there is a clear separation between the terms of "Commander" and "Leader" and between the terms "Management" and "decision-making procedure". According to the Field Manual 181-1 "Management and Leadership":

"... Command in the AF is the legally exercised power by a person to his subordinates, which stems from his rank and the duties entrusted to him or by his hierarchical level. This power comes with the Commander's responsibility to his superiors and subordinates to carry out the mission entrusted to him. Management in the Army is founded legally according to the Military and Joint Criminal Code.

Management is the operation of planning, organizing, coordinating, directing and controling of personnel, tools, materials time and money that are available, for the successful implementation of a specific mission.

Leadership is defined as the art by which a leader influences and directs others in such a way as to gain their trust, obedience, respect, cooperation between individuals and their faithful dedication to achieve a common purpose ..." (Hellenic Army General Staff, 1988).

Military administration - and as such it will be understood hereinafter the command of troops from their natural leaders presents some peculiarities in comparison with other forms of administration, such as public administration, church administration etc., due to the following major reasons:

(1) Military administration's target is to prepare troops for war

(2) For the above reason, a military commander is imposing a high degree of discipline

(3) Military administration is sometimes exercised in very dangerous and difficult circumstances, such as war or crucial situations

(4) Good or bad military administration could directly affect the lives of troops and in wartime is directly related to homeland security

The main differences between a military commander and a manager are (Hellenic Army General Staff, 1989):

(1) The commander does not select and then hire his staff. Soldiers are placed to units according to their rank and their specialty. If he has not enough personnel or the troops' skills are not the appropriate, then he should do his best with it. 
(2) The staff turnover is much frequent than in a business. A manager has no problems of frequent staff rotations, unlike the military leader.

(3) Soldiers are much younger than most personnel in any business. The majority of them have not worked again. Many had never even been away from their home. All of them need to learn and adapt to a completely new lifestyle when they join the army.

(4) The Commander has more power to personnel than any manager. Soldiers may be punished or penaised for acts that in a job in civilian life would go unnoticed.

(5) The Commander has a great responsibility for his soldiers. He is responsible for their actions not only during their service but also on their free time outside the unit, which is not usually the case in companies.

(6) When the Commander considers necessary that the personnel have to work overtime to carry out their mission, soldiers are not getting additional payment for overtime.

(7) However, the most important of all is that the Commander expects his troops to accept the possibility of dying on the battlefield in order to carry out their mission.

In the AF it is also possible to control effectively and to determine the person responsible for the best execution of each mission (Saiti, 2008; Saitis, 2008) and the Service must make sure that in critical positions there are officers who possess the decision-making skill, or, in other words, who have the conditions to be qualified as "leaders" (Saitis, 2014).

\section{Methodology}

In order to conduct this research, 50 officers provided relevant information by answering a set of 45 close-ended questions specifically designed for the survey, with a response rate of $100 \%$. Data elaboration and statistical analysis were performed. All results of descriptive statistics among the variables are presented and a comment analysis of key results has been made, with some additional proposals.

\section{Analysis of Results}

\section{A. Participants' profile}

The male officers' percentage (86\%) was significally higher than that of females (14\%). $36 \%$ of them hold the rank of Major, $28 \%$ the rank of Captain, $26 \%$ the rank of Lieutenant Colonel and the rest of them serve as Second Lieutenants, Colonels. It is worth mentioning that most of the respondents serve to Attiki region (46\%), almost one in five (18\%) serves in border region and specifically in Thrace, $16 \%$ serves in Macedonia region and the rest of them serve in Sterea Region, Epirus and Islands. The biggest sample (42\%) has an experience of 21 to 30 years of service in the Army and a $38 \%$ has a similar experience of 11 to 20 years. The respondants' field of duty is in Administration at the largest percentage (38\%) whereas the $22 \%$ attends higher Army Academies. As far as education level is concerned, $44 \%$ stated that they have a University degree, $30 \%$ reported that besides their basic Army School graduation they have no other educational diploma, $18 \%$ holds a master degree and only a $2 \%$ holds a PhD Diploma. $84 \%$ of the officers' sample are married, $14 \%$ are single and $2 \%$ or divorced.

As far as their educational training-besides all basic Army Schools- $80 \%$ stated that they have been trained and most of them $(62 \%)$ have been trained interservice. The rest of them are spit to several training cources from Municipalities, from Private Sector, from Univercities etc. Almost all of them (94\%) are familiar with one foreign language. Half of them speak fluently the English language.

B. Special questions. Some interesting results came up when data elaboration was performed. $54 \%$ of the sample stated that their immediate supervisor officer very often/always provides assistance, in return of their effords. Almost half of the respondants $(46 \%)$ said that their supervisor never/rarely avoids to interfer to a problem, until it becomes serius. $80 \%$ of them also stated that their supervisor never/rarely avoids getting involved when important issues arise. He also never/rarely (at a percentage of $92 \%$ ) is absent when there is a need. $74 \%$ of the officers said that their supervisor often/very often makes them feel prood of him. $78 \%$ believes that the supervisor often/very often states clearly who is responsible for 
achieving specific objectives. He never/rarely waits until something goes wrong to intervene, as $76 \%$ said, and speaks often/very often in an enthousiastic way about the needs to be fulfilled (74\%). $82 \%$ said that he never/rarely seems to be stable in the point of view: if something is broken, don't fix it" and $84 \%$ states that he never/rarely avoids making decisions. Additionally he very often/always (at a percentage of $72 \%$ of the respondants) determines the importance of having a strong sense of purpose. However, only half of them (56\%) believe that their supervisor often/very often set the teams' good above personal interest, but when it comes to teaching and guiding, $62 \%$ feel that he can often/very often manage that in a successful way. $66 \%$ of the sample has the opinion that his supervisor works in a way that earns officers' respect, although $68 \%$ thinks that the supervisor monitors every mistake they make.

It is worth mentioning that the supervisor refers to his own values and beliefs at a range of $28 \%$ rarely, $30 \%$ often and $22 \%$ very often, and speaks with optimism about the future in a same way ie rarely $20 \%, 30 \%$ often and $32 \%$ very often. $\mathrm{He}$ also seems to focus his attention to errors, exceptions and irregularities from standards at a percentage of $22 \%$ rarely, $30 \%$ often ans $38 \%$ very often. Into the same average result to the question of the frequence of treating the officer as an indivisual rather that a simple member of a group, since the outcome is: rarely at the percentage of $24 \%$, often at $20 \%$ and very often at $24 \%$. The officers highly believe $(70 \%)$ think that he often/very often helps them develop their own potential and that he urges to see problems sphairically. He also is thought to often/very often emphasize on the importance of a collective sense of mission (62\%). Generally, supervisors are thought to often/very often respond to officers' job needs $(66 \%)$. They also use often/very often (74\%) satisfactory leadership methods and work very often/always with satisfaction with the officers, so they often/very often manage to increase desire for success and respond effectively to Services' requirements. In that way, supervisors at a high level $(68 \%)$ often/very often increase officers' willingness to do more and manage very often/always $(70 \% 0$ to lead their team effectively.

\section{Discussion}

Through observation and all data analysis, literature seems to be confirmed as far as the main factors that effectively influence the motivation for efficient work in the army. In more detail, it is clear that the majority of army personel want to be satisfied by their own personal efforts and have a highly developed sense of their duty. They also have a well developed desire for stability and secutity in their unit and believe that their Supervisor's actions will make them proud for serving in the specific unit. As long as inspiration and motivation are conserned, the majority believes that their Supervisor explains the necessity of each task to be performed and that their efforts are recognized, in the form of moral compensations. Moreover, it seems that the Supervisor inspires faith, trust, respect, internal discipline and morale to his personel.

On the other hand, there are not clear conclusions on the Supervisors behavior, regarding his optimistic approach about the future, about his focusing on errors and deviations from the standard and about referring to his personal beliefs and values. There is also not a clear aspect whether the Supervisor has the ability to represent his personel's needs and suggestions to higher ranking levels and about his effectiveness to treats his subordinates as individuals or as members of a group (unit).

It is obvious from the MLQ results that the style of Avoidant Full Range leadership is not observed in the Hellenic AF. The tendency is to accept the Transactional style as dominant, but more elaboration is needed in order to conclude safely. Also data elaboration and statistical analysis show that Leadership Outcomes - Extra Effort, Effectiveness and Satisfaction have a result that also is tending to accept Effectiveness as a potential vision.

\section{Proposals}

Through this first attempt in monitoring and seeking a leadership style based on a personal level to be exercised within the framework of strict structures of HR, it is clear that certain tentions exist in the Hellenic AF, which should be further studied and analysed in order to establish concrete conclusions. Additionally, there are certain factors that need to be studied so to form a more clear opinion of the personel questioned.

It is derived from the existing data that there is a need for motivating Supervisors to avoid focusing their attention to monitoring and confronting mistakes, failures and complaints. It is also clear that subordinates think their Supervisor is using satisfactory leadership methods, so there is no need to dramatically change any leader's training course. 
In this specific study, the effects of the economic crisis in Greece were not taken into account in MLQ, so there cannot be any conclusion regarding the Supervisor's approach to the financial problems of his staff that affect their work production.

\section{References}

[1] Dawson, T., (1993), Principles of Practice of Modern Management, Tudor Business Publishing Ltd

[2] Hellenic Army General Staff, (1988), Field Manual 181-1 (FM 181-1, Command and Leadership), Athens

[3] Hellenic Army General Staff, (1989), Field Manual 181-3 (FM 181-3, Management), Athens

[4] Karageorgou, E. \& Stefou, T., (2014), The teacher as a leader in educational project management in Second Chance Schools. Perceptions of Greek Adult Students, in: International Conference on Advances in Management, Economics and Social Science MES 2014, Italy: Rome

[5] Niveroglou, G., (2008), Leadership opposed to Administrative Management in the Armed Forces, Master Thesis. Thessaloniki: Supreme Joint War College

[6] Saiti, A., (2008), Educational evaluation, Pedagogical Training of OAED Education, School of Pedagogical and Technological Education (ASPAITE), University of Athens (UOA), Recovery from http://hdl.handle.net/10795/1099

[7] Saitis, C., (2008), Organization and Management of Education, Athens: Self edition

[8] Saitis, C., (2014), Initiation of teachers in the secrets of school leadership, Athens: Self edition

TABLE 1

\begin{tabular}{|c|c|c|c|c|c|}
\hline $\begin{array}{l}\text { My immediate supervisor (Degree of acceptance of the following } \\
\text { sentences by the respondants (\%) }\end{array}$ & Never & Rarely & Often & Very Often & Always \\
\hline 1. Provides assistance, in return for my efforts & 0 & 20 & 26 & 40 & 14 \\
\hline $\begin{array}{l}\text { 2. Reviews critical elements that are taken for granted and wonders if } \\
\text { they are suitable }\end{array}$ & 0 & 18 & 40 & 28 & 14 \\
\hline 3. Does not interfere until the problem become serious & 12 & 34 & 32 & 14 & 8 \\
\hline $\begin{array}{l}\text { 4. Focuses his attention to irregularities, errors, exceptions and } \\
\text { deviations from standards. }\end{array}$ & 8 & 22 & 30 & 38 & 2 \\
\hline 5. Avoids getting involved when important issues arise & 36 & 44 & 16 & 2 & 2 \\
\hline 6. Refers to his own important values and beliefs & 10 & 28 & 30 & 22 & 10 \\
\hline 7. Is absent when is need. & 56 & 36 & 6 & 2 & 0 \\
\hline 8. Looks for different perspectives in addressing problems & 4 & 20 & 40 & 28 & 8 \\
\hline 9. Speaks with optimism about the future & 2 & 20 & 30 & 32 & 16 \\
\hline 10. Makes me feel proud for cooperating with him & 2 & 8 & 28 & 46 & 16 \\
\hline 11. States clearly who is responsible for achieving specific objectives & 2 & 4 & 34 & 44 & 16 \\
\hline 12. Waits for something to go wrong to intervene & 28 & 48 & 10 & 12 & 2 \\
\hline 13. Speaks enthusiastically about the needs to be met & 4 & 10 & 38 & 36 & 12 \\
\hline 14. Determines the importance, having a strong sense of purpose & 2 & 0 & 26 & 48 & 24 \\
\hline 15. Devotes time to teaching and guiding & 2 & 16 & 38 & 24 & 20 \\
\hline $\begin{array}{l}\text { 16. Makes clear of what result should anyone wait to get when the } \\
\text { objectives are achieved }\end{array}$ & 4 & 10 & 32 & 42 & 12 \\
\hline
\end{tabular}




\begin{tabular}{|c|c|c|c|c|c|}
\hline $\begin{array}{l}\text { 17. Seems to be stable in the view: "If something is broken, do not fix } \\
\text { it." }\end{array}$ & 54 & 28 & 10 & 2 & 6 \\
\hline 18. Puts the good of the team above personal interest & 4 & 22 & 30 & 26 & 18 \\
\hline $\begin{array}{l}\text { 19. Treats me more like a separate individual rather than simply as a } \\
\text { member of the group }\end{array}$ & 10 & 24 & 30 & 24 & 12 \\
\hline $\begin{array}{l}\text { 20. Follows the tactics that problems must exist for long before take an } \\
\text { action. }\end{array}$ & 58 & 18 & 14 & 6 & 4 \\
\hline 21. Works in a way that earns my respect & 2 & 8 & 24 & 42 & 24 \\
\hline $\begin{array}{l}\text { 22. Focuses his attention solely to monitoring and confronting } \\
\text { mistakes, complaints and failures }\end{array}$ & 12 & 28 & 46 & 10 & 4 \\
\hline 23. Thiks the ethical consequences of decisions & 2 & 14 & 42 & 26 & 16 \\
\hline 24. Monitors every mistake made & 0 & 14 & 44 & 24 & 18 \\
\hline 25. Demonstrates a sense of strength and confidence & 0 & 6 & 26 & 42 & 26 \\
\hline 26. Displays an exciting vision for the future & 6 & 30 & 32 & 26 & 6 \\
\hline 27. Drews my attention when I do not meet the standards. & 4 & 20 & 44 & 26 & 6 \\
\hline 28. Avoids making decisions & 44 & 40 & 10 & 4 & 2 \\
\hline $\begin{array}{l}\text { 29. Faces me, compared with others, as an individual with different } \\
\text { needs, abilities and aspirations }\end{array}$ & 18 & 28 & 30 & 14 & 10 \\
\hline 30. Urges me to see problems from many different angles & 4 & 12 & 36 & 34 & 14 \\
\hline 31. Helps me develop my potential & 4 & 12 & 26 & 44 & 14 \\
\hline 32. Proposes new ways to complete a project & 2 & 14 & 28 & 38 & 18 \\
\hline 33. Delays to provide a solution to urgent issues & 40 & 44 & 10 & 0 & 6 \\
\hline $\begin{array}{l}\text { 34. Emphasizes how important it is to have a collective sense of } \\
\text { mission }\end{array}$ & 2 & 10 & 40 & 32 & 16 \\
\hline 35. Welcomes my responce to his expectations & 2 & 10 & 24 & 44 & 20 \\
\hline 36. Expresses his confidence that the objectives will be achieved & 2 & 6 & 30 & 44 & 18 \\
\hline 37. Responds effectively to my job needs & 2 & 12 & 24 & 42 & 20 \\
\hline 38. Uses satisfactory leadership methods & 4 & 10 & 20 & 54 & 12 \\
\hline 39. Manages to make me do more than I would expect & 4 & 24 & 32 & 32 & 8 \\
\hline 40. Represents me effectively at senior levels & 6 & 16 & 24 & 32 & 22 \\
\hline 41. Works with me satisfactorily & 2 & 4 & 20 & 42 & 32 \\
\hline 42. Increases desire for success & 4 & 6 & 28 & 46 & 16 \\
\hline 43. Responds effectively to the requirements of the Service & 0 & 4 & 22 & 40 & 34 \\
\hline 44. Increases my willingness to try more & 2 & 12 & 24 & 44 & 18 \\
\hline 45. Leads a team that is effective & 2 & 14 & 14 & 52 & 18 \\
\hline
\end{tabular}

